\title{
Pengkayaan ilmu petugas puskesmas sebagai langkah penurunan angka anemia di Kabupaten Sleman
}

\author{
Emy Huriyati, ${ }^{1}$ Tri Ratnaningsih, ${ }^{2}$ Abdul Wahab, ${ }^{3}$ Arta Farmawati, ${ }^{4}$ Nur Imma Fatimah Harahap, ${ }^{2}$ \\ Ainun Nisa ${ }^{1, *}$ \\ ${ }^{1}$ Departemen Gizi Kesehatan, Fakultas Kedokteran, Kesehatan Masyarakat, dan Keperawatan, \\ Universitas Gadjah Mada, Yogyakarta, Indonesia \\ 2Departemen Patologi Klinik dan Kedokteran Laboratorium, Fakultas Kedokteran, Kesehatan Masyarakat, \\ dan Keperawatan, Universitas Gadjah Mada, Yogyakarta, Indonesia \\ ${ }^{3}$ Departemen Biostatistik Epidemiologi dan Kesehatan Masyarakat, Fakultas Kedokteran, Kesehatan \\ Masyarakat, dan Keperawatan, Universitas Gadjah Mada, Yogyakarta, Indonesia \\ ${ }^{4}$ Departemen Biokimia, Fakultas Kedokteran, Kesehatan Masyarakat, dan Keperawatan, Universitas \\ Gadjah Mada, Yogyakarta, Indonesia
}

\section{Submitted: 4 September 2018 Revised: 27 Oktober 2018 Accepted: 6 November 2018}

\begin{abstract}
ABSTRAK Fokus Dinas Kesehatan Kabupaten Sleman untuk menanggulangi anemia saat ini bukan hanya pada ibu hamil saja, melainkan juga sudah menyasar remaja putri, jauh sebelum mereka hamil. Langkah pemerintah dalam menanggulangi anemia dengan suplementasi besi dikhawatirkan tidak tepat sasaran. Sejauh ini deteksi anemia oleh petugas puskesmas hanya sebatas pemeriksaan hemoglobin saja dan kejadian anemia yang terdeteksi masih bersifat umum, tidak khusus untuk anemia defisiensi besi. Subjek penelitian ini adalah petugas puskesmas yang meliputi dokter, ahli gizi, dan ahli teknologi laboratorium medis yang dipilih secara purposive sampling. Metode yang digunakan dalam penelitian ini adalah pelatihan dengan rangkaian kegiatan berupa penyuluhan dengan pre-test dan post-test, tutorial kasus, dan praktikum. Untuk mengetahui ada tidaknya peningkatan pengetahuan, dilakukan analisis data menggunakan paired $t$-test pada nilai pre-test dan post-test. Uji statistik dinyatakan bermakna bila nilai $p$ kurang dari 0,05 . Total peserta yang mengikuti penelitian adalah 71 orang. Pelatihan terkait anemia defisiensi besi untuk petugas puskesmas dapat meningkatkan tingkat pemahaman sebesar 32,8 poin $(p<0,0001)$, yang merupakan selisih nilai pre-test dan post-test. Pemilihan metode pelatihan sudah tepat karena hasil evaluasi kegiatan menunjukkan bahwa sebagian besar peserta menilai metode pelatihan efektif atau sangat efektif $(74,7 \%)$. Program pelatihan dapat meningkatkan pemahaman petugas puskesmas di Kabupaten Sleman terkait anemia defisiensi besi.
\end{abstract}

KATA KUNCI pelatihan; puskesmas; pengetahuan; anemia defisiensi besi

ABSTRACT The focus of the Sleman District Health Office in the prevention of anemia is not only on pregnant women anymore as it currently involves young women, long before they become pregnant. The government's step in overcoming anemia with iron supplementation is argued to fail to hit the target. So far the detection of anemia by health center officials is only limited to hemoglobin examination, indicating that the detection of anemia is still general and not specific to iron deficiency anemia. The subjects of this study were community health center staffs including doctors, nutritionists, and medical laboratory technology experts who were chosen by purposive sampling. The methods used were training with a series

\footnotetext{
*Corresponding author: Ainun Nisa

Departemen Gizi Kesehatan, Fakultas Kedokteran, Kesehatan Masyarakat, dan Keperawatan, Universitas Gadjah Mada, Jl. Farmako, Sekip Utara, Yogyakarta 55281, Indonesia

E-mail: ainunisa2@gmail.com
} 
of activities, namely lecture with pre-test and post-test, case tutorials, and practical work. To assess the improvement in knowledge, paired t-test was performed to compare the difference of value between pretest and post-test. P-value of less than 0.05 was considered statistically significant. The total participants who took part in the activity were 71 people. Training related to iron deficiency anemia for health center officers can increase the level of understanding by 32.8 points $(p<0.0001)$. The methods chosen for training activities were considered appropriate with around three-quarters (74.7\%) of the participants rated the training method effective or very effective. The training program can improve the understanding of health center staff in Sleman Regency regarding iron deficiency anemia.

KEYWORDS training; community health center; knowledge; iron deficiency anemia

\section{Pendahuluan}

Anemia defisiensi besi akan berpengaruh pada ketahanan terhadap infeksi yang mengakibatkan tingginya angka morbiditas dan terhambatnya kemampuan belajar, produktivitas kerja, perilaku, serta perkembangan otak. ${ }^{1,2}$ Anemia defisiensi besi dapat disebabkan baik oleh pendarahan yang terjadi menahun, rendahnya asupan besi ke dalam tubuh, terjadi gangguan absorpsi dalam tubuh, maupun karena kebutuhan besi yang meningkat. ${ }^{3}$ Faktor lain yang berpengaruh terhadap kejadian anemia antara lain gaya hidup seperti merokok, minum minuman keras, kebiasaan sarapan pagi, keadaan ekonomi dan demografi, pendidikan, umur, jenis kelamin, dan wilayah. ${ }^{4}$

Angka anemia pada ibu hamil secara nasional menurut Riskesdas 2013 adalah 37,1\%, angka kejadian pada penduduk pedesaan $(37,8 \%)$ lebih tinggi dibanding penduduk kota $(36,4 \%) .{ }^{5}$ Menurut data dari Dinas Kesehatan Kabupaten Sleman pada tahun 2017, prevalensi anemia ibu hamil di Kabupaten Sleman sebesar 8,1\% dengan prevalensi paling tinggi di wilayah kerja Puskesmas Prambanan yang mencapai $21,4 \%$, disusul oleh Puskesmas Godean II (18,5\%) dan Puskesmas Tempel I (15,7\%). ${ }^{6}$

Fokus Dinas Kesehatan Kabupaten Sleman untuk penanggulangan anemia dewasa ini bukan hanya pada ibu hamil saja, melainkan juga sudah menyasar remaja putri, jauh sebelum mereka hamil. Dinas Kesehatan Kabupaten Sleman bekerja sama dengan Universitas Gadjah Mada di tahun 2017 mengadakan program deteksi anemia pada remaja putri di wilayah kerja Puskesmas Godean. Hasil penelitian tersebut menunjukkan bahwa prevalensi anemia pada remaja putri mencapai $12,7 \%$ dan remaja putri yang mengalami kurang energi kronis (KEK) sebesar 44,7\%. Faktor- faktor yang berhubungan dengan kejadian anemia yang teridentifikasi melalui wawancara kuesioner adalah pengetahuan tentang anemia yang kurang, kondisi kesehatan dan kebiasaan makan yang kurang baik, serta tingkat sosial ekonomi menengah ke bawah. Sebagian besar remaja puteri mempunyai riwayat menstruasi yang normal, tetapi ada hubungan antara volume darah menstruasi dengan kejadian anemia. $^{7}$

Langkah pemerintah dalam menanggulangi anemia dengan pemberian suplementasi besi dikhawatirkan tidak tepat sasaran karena kejadian anemia yang terdeteksi masih bersifat umum, tidak spesifik anemia defisiensi besi. Padahal, terdapat beberapa jenis anemia dengan penyebab yang bervariasi. Menurut penelitian Ringorongo, ${ }^{8}$ definisi anemia defisiensi besi adalah apabila kadar $\mathrm{Hb}<11 \mathrm{~g} / \mathrm{dl}$ disertai 1 atau 2 kriteria berikut yang terpenuhi, yaitu red cell distribution width (RDW) $=15 \%$ atau indeks Mentzer $>13$. Indeks Mentzer adalah nilai yang diperoleh dari mean corspuscular volume (MCV): red blood cell (RBC) dalam juta/ $\mathrm{mm}^{3}$. Index ini digunakan untuk membedakan anemia defisiensi besi dengan talasemia minor/ trait. Bila nilai indeks Mentzer < 13 maka pasien diduga menderita talasemia minor/trait; sedangkan bila nilai indeks Mentzer > 13 maka pasien diduga menderita anemia defisiensi besi. ${ }^{8}$ Berdasarkan data dari Dinas Kesehatan Sleman, metode tersebut belum pernah digunakan dalam 
program deteksi kejadian anemia defisiensi besi di Kabupaten Sleman. Pemeriksaan laboratorium untuk deteksi anemia defisiensi besi hanya dengan pengukuran kadar hemoglobin sehingga perlu pengenalan metode dan ilmu baru dan sederhana kepada petugas puskesmas untuk deteksi spesifik anemia defisiensi besi.

Pada pasien talasemia, pem-bentukan hemoglobin tidak sempurna sehingga sel darah merah mudah rusak atau berumur pendek. ${ }^{9}$ Pemberian suplementasi $\mathrm{Fe}$ pada penderita talasemia dapat memicu terjadinya kelebihan besi. Kadar feritin (simpanan besi) yang tinggi dapat menghambat absorbsi seng, perubahan toksik pada jaringan melalui pelepasan radikal bebas yang menginduksi stres oksidatif, dan peroksidasi membran lipid yang dapat menimbulkan efek toksik pada jantung dan jaringan lain. ${ }^{9}$

Berdasarkan paparan di atas, muncul ide untuk menyelenggarakan kegiatan pengabdian sekaligus penelitian yang bersifat multidisiplin kepada tenaga kesehatan di puskesmas, di Kabupaten Sleman. Pengadaan workshop peningkatan mutu laboratorium dan edukasi gizi diharapkan dapat menjembatani dalam memecahkan masalah yang dihadapi mitra. Menurut Dinas Kesehatan Sleman, beberapa tahun belakangan ini angka anemia defisiensi besi di Kabupaten Sleman tidakmengalami penurunan drastis dibanding tahun sebelumnya, padahal program suplementasi zat besi sudah dilaksanakan. Oleh karena itu, pengkayaan ilmu petugas puskesmas diharapkan dapat memberikan peningkatan pemahaman terkait ilmu dan metode sederhana untuk deteksi anemia defisiensi besi. Penelitian ini bertujuan untuk menilai efektivitas pelatihan yang dilakukan dalam meningkatkan pemahaman tenaga kesehatan di puskesmas. Hasil penelitian ini juga diharapkan dapat menjadi dasar dalam perumusan kebijakan untuk menanggulangi masalah anemia defisiensi besi.

\section{Metode}

\subsection{Subjek dan lokasi kegiatan}

Penelitian ini merupakan salah satu rangkaian kegiatan yang dilaksanakan di Kabupaten Sleman pada bulan April - Agustus 2018 yang terdiri dari koordinasi tim, koordinasi dengan pihak Dinas Kesehatan Sleman, penyusunan materi dan modul kegiatan, dan pelatihan petugas puskesmas. Koordinasi tim dan koordinasi dengan pihak terkait terdiri daro rapat rutin dan rapat perkembangan rencana program penyuluhan, serta penetapan jadwal dan koordinasi jadwal dengan pihak puskesmas. Penyusunan materi dan modul kegiatan terdiri atas penyusunan jadwal, pemilihan topik tambahan terkait anemia, serta penyusunan materi penyuluhan. Materi penyuluhan terdiri dari pengantar anemia dan 1000 hari pertama kehidupan (HPK), deteksi anemia defisiensi besi berdasarkan pemeriksaan laboratorium, surveilans anemia di komunitas, dan nutrisi pada anemia.

Peneliti mengundang 75 orang yang merupakan petugas kesehatan yang dipilih secara purposive sampling dan mewakili semua puskesmas di Kabupaten Sleman untuk mengikuti pelatihan. Peserta terdiri dari petugas gizi, dokter, dan ahli teknologi laboratorium medis (ATLM) masing-masing berjumlah 25 orang. Puskesmas yang berpartisipasi adalah Puskesmas Berbah, Cangkringan, Depok I, Depok II, Depok III, Gamping I, Gamping II, Godean I, Godean II, Kalasan, Minggir, Mlati I, Mlati II, Moyudan, Ngaglik I, Ngaglik II, Ngemplak I, Ngemplak II, Pakem, Prambanan, Seyegan, Sleman, Tempel I, Tempel II, dan Turi.

\subsection{Metode pelaksanaan kegiatan}

Fokus utama kegiatan yang dilakukan adalah pelatihan petugas puskesmas terkait anemia defisiensi besi. Kegiatan ini terdiri dari penyuluhan, diskusi kasus, dan praktikum.

\subsubsection{Penyuluhan}

Penyuluhan merupakan suatu metode promosi kesehatan yang dilakukan dengan menyebarkan informasi dan menanamkan keyakinan sehingga masyarakat tidak hanya sadar dan tahu, namun juga mau dan mampu melakukan perbaikan perilaku. Pada metode ini, subjek diberikan pemahaman mengenai anemia defisiensi besi dan metode sederhana yang dapat diterapkan oleh petugas 
laboratorium dalam mendeteksi kejadian anemia defisiensi besi. Terdapat empat sesi dalam setiap penyuluhan, yaitu pre-test, pemberian materi, diskusi dan tanya jawab, serta post-test.

\subsubsection{Tutorial}

Tujuan dari metode ini adalah untuk memberikan kesempatan kepada setiap peserta untuk mengembangkan kemampuan memecahkan masalah secara rasional dan mendinamiskan kegiatan kelompok dalam belajar sehingga tiap anggota merasa diri sebagai anggota kelompok dan berperan aktif dalam pemecahan masalah. Tutorial bermanfaat untuk mempertajam pengetahuan dan mengembangkan materi dasar yang diberikan saat ceramah atau penyuluhan. Pada kegiatan ini, metode tutorial dilaksanakan oleh petugas gizi puskesmas dalam tutorial kasus anemia defisiensi besi, terkait dengan pemecahan masalah dan rancangan program penanggulangan anemia defisiensi besi.

\subsubsection{Praktik}

Tujuan metode ini adalah agar peserta memiliki keterampilan yang lebih baik daripada sebelumnya, mengaplikasikan teori yang telah diberikan, dan merasakan bagaimana melakukan pemeriksaan dengan benar. Metode praktik diterapkan agar peserta semakin memahami materi yang diberikan yaitu pengukuran hemoglobin, angka eritrosit, hematokrit, indeks eritrosit, retikulosit, dan morfologi darah tepi.

\subsection{Analisis data}

Tujuan dari kegiatan ini adalah adanya peningkatan pemahaman peserta kegiatan setelah mendapatkan pelatihan. Untuk mengetahui dampak pelatihan terhadap pemahaman peserta terkait anemia, dilakukan paired t-test pada nilai pre-test dan posttest. Hasil uji statistik dikatakan bermakna bila nilai $p$ kurang dari 0,05. Rerata nilai pre-test dan posttest disajikan dalam tabel rerata dan simpangan baku. Selain itu, evaluasi kegiatan disajikan dalam tabel frekuensi dan grafik.

\section{Hasil}

Peserta kegiatan merupakan petugas kesehatan di puskesmas di Kabupaten Sleman, yang terdiri dari dokter, ahli gizi, dan ATLM. Tingkat partisipasi peserta adalah 94,7\%. Dari 75 orang yang diundang, 71 orang mengikuti pelatihan. Hasil rerata nilai pre-test dan post-test pengkayaan ilmu petugas kesehatan berdasarkan asal puskesmas disajikan pada Tabel 1. Hampir semua subjek kegiatan mengalami peningkatan nilai post-test jika dibandingkan dengan nilai pre-test.

Setelah dilakukan paired t-test, diketahui bahwa penyampaian materi penyuluhan berdampak positif menaikkan pemahaman peserta. Hal ini dapat dilihat dari data rerata nilai pre-test sebesar $49,2 \pm 12,2$ dan rerata nilai post-test sebesar $82,0 \pm$ 12,3. Delta kenaikan sebesar 32,8 ( $p<0,0001)$.

Pelaksanaan kegiatan tentunya tidak lepas dari evaluasi kegiatan. Evaluasi kegiatan dilakukan dengan pengisian formulir evaluasi oleh peserta. Formulir berisi pertanyaan terkait topik, metode pelatihan, dan dampak pelatihan. Sebagian besar aspek penyuluhan telah berjalan dengan baik dan dapat diterima oleh peserta kegiatan. Hasil evaluasi kegiatan dapat dilihat pada Gambar 1, 2, dan 3.

\section{Pembahasan}

Sebagai langkah awal dalam menurunkan angka anemia defisiensi besi di masyarakat Kabupaten Sleman, pengkayaan ilmu dan wawasan petugas puskesmas merupakan langkah yang tepat. Puskesmas merupakan salah satu sarana pelayanan kesehatan di tingkat dasar atau fasilitas kesehatan tingkat pertama yang diharapkan dapat memberikan pelayanan kesehatan yang bermutu, memuaskan, dan sesuai standar dan etika profesi. Puskesmas adalah unit pelaksana teknis (UPT) dari dinas kesehatan kabupaten/ kota yang bertanggung jawab menyelenggarakan pembangunan kesehatan di satu atau sebagian wilayah kecamatan. ${ }^{10}$

Pelayanan kesehatan masyarakat adalah pelayanan yang bersifat publik yang bertujuan 
Tabel 1. Rerata nilai pre-test dan post-test peserta penyuluhan dari 25 puskesmas di Kabupaten Sleman

\begin{tabular}{|c|c|c|c|}
\hline Puskesmas & Nilai pre-test & Nilai post-test & Delta kenaikan \\
\hline Berbah & $46,7 \pm 12,6$ & $55,0 \pm 47,7$ & 8,3 \\
\hline Cangkringan & $48,3 \pm 5,8$ & $78,3 \pm 15,3$ & 30,0 \\
\hline Depok I & $33,3 \pm 29,3$ & $80,0 \pm 5,00$ & 46,7 \\
\hline Depok II & $52,5 \pm 3,5$ & $87,5 \pm 3,5$ & 35,0 \\
\hline Depok III & $58,3 \pm 2,9$ & $83,3 \pm 2,9$ & 25,0 \\
\hline Gamping I & $48,3 \pm 2,9$ & $73,3 \pm 16,1$ & 25,0 \\
\hline Gamping II & $58,3 \pm 2,9$ & $78,3 \pm 7,6$ & 10,0 \\
\hline Godean I & $46,7 \pm 7,6$ & $78,3 \pm 7,6$ & 31,7 \\
\hline Godean II & $42,5 \pm 17,7$ & $85,0 \pm 0,0$ & 42,5 \\
\hline Kalasan & $26,7 \pm 5,8$ & $86,7 \pm 2,9$ & 60,0 \\
\hline Minggir & $53,3 \pm 11,6$ & $85,0 \pm 8,7$ & 31,7 \\
\hline Mlati I & $45,0 \pm 10,0$ & $81,7 \pm 7,6$ & 36,7 \\
\hline Mlati II & $51,7 \pm 2,9$ & $86,7 \pm 5,8$ & 35,0 \\
\hline Moyudan & $61,7 \pm 2,9$ & $85,0 \pm 0,0$ & 23,3 \\
\hline Ngaglik I & $51,6 \pm 7,6$ & $80,0 \pm 5,0$ & 28,4 \\
\hline Ngaglik II & $45,0 \pm 0,0$ & $87,5 \pm 3,5$ & 42,5 \\
\hline Ngemplak I & $60,0 \pm 5,0$ & $88,3 \pm 2,9$ & 28,3 \\
\hline Ngemplak II & $55,0 \pm 13,2$ & $85,0 \pm 5,0$ & 30,0 \\
\hline Pakem & $53,3 \pm 10,4$ & $90,0 \pm 0,0$ & 36,7 \\
\hline Prambanan & $46,7 \pm 11,6$ & $91,7 \pm 2,9$ & 45,0 \\
\hline Seyegan & $58,3 \pm 5,8$ & $85,0 \pm 0,0$ & 26,7 \\
\hline Sleman & $56,3 \pm 8,5$ & $78,8 \pm 10,3$ & 22,5 \\
\hline Tempel I & $35,0 \pm 7,07$ & $82,5 \pm 10,6$ & 47,5 \\
\hline Tempel II & $31,7 \pm 2,9$ & $80,0 \pm 0,0$ & 48,3 \\
\hline Turi & $55,0 \pm 0,0$ & $82,5 \pm 3,5$ & 27,5 \\
\hline Total & $49,2 \pm 12,2$ & $82,0 \pm 12,3$ & 32,8 \\
\hline
\end{tabular}

Nilai pre-test dan post-test dinyatakan dalam rerata \pm simpangan baku

untuk memelihara dan meningkatkan derajat kesehatan dengan mencegah dan menyembuhkan penyakit. Adapun jenis pelayanan dari puskesmas antara lain promosi kesehatan, pemberantasan penyakit, penyehatan lingkungan, perbaikan gizi, peningkatan kesehatan keluarga, keluarga berencana, kesehatan jiwa masyarakat serta berbagai program kesehatan masyarakat lainnya. Oleh karena itu, puskesmas merupakan pelayanan kesehatan yang paling dekat dan lengkap dalam merangkul masyarakat.
IImu yang didapatkan dari pelatihan petugas puskesmas di Kabupaten Sleman ini diharapkan dapat diaplikasikan oleh petugas kesehatan di wilayah kerja masing-masing untuk mendeteksi anemia defisiensi besi secara spesifik sehingga intervensi dengan pemberian tablet besi lebih tepat sasaran. Dengan keberhasilan pelatihan di Kabupaten Sleman, tidak menutup kemungkinan bahwa pelatihan dengan metode yang sama dapat diterapkan di kabupaten lain di Daerah Istimewa Yogyakarta. 


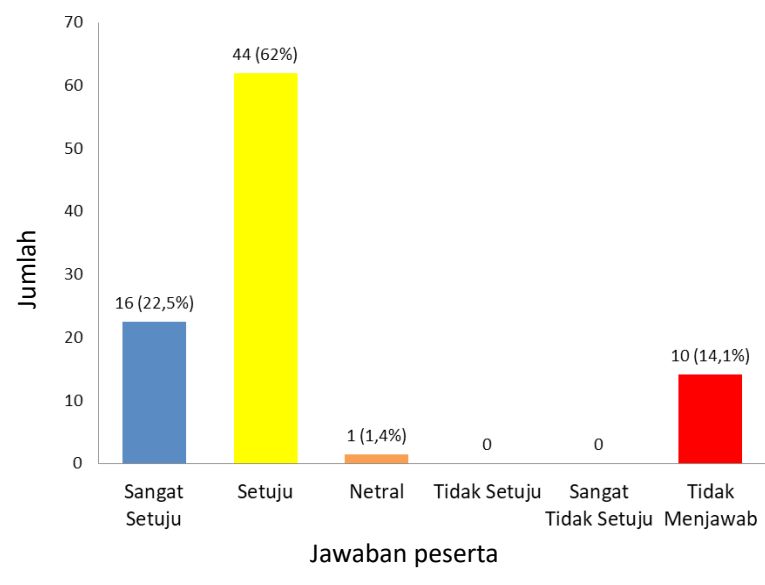

Gambar 1. Jawaban peserta terhadap pertanyaan apakah pelatihan dapat meningkatkan wawasan

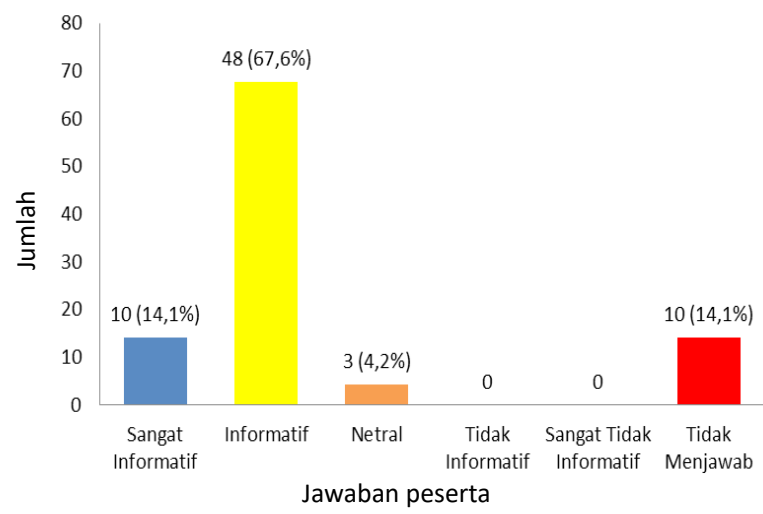

Gambar 2. Jawaban peserta terhadap pertanyaan bagaimana materi pelatihan

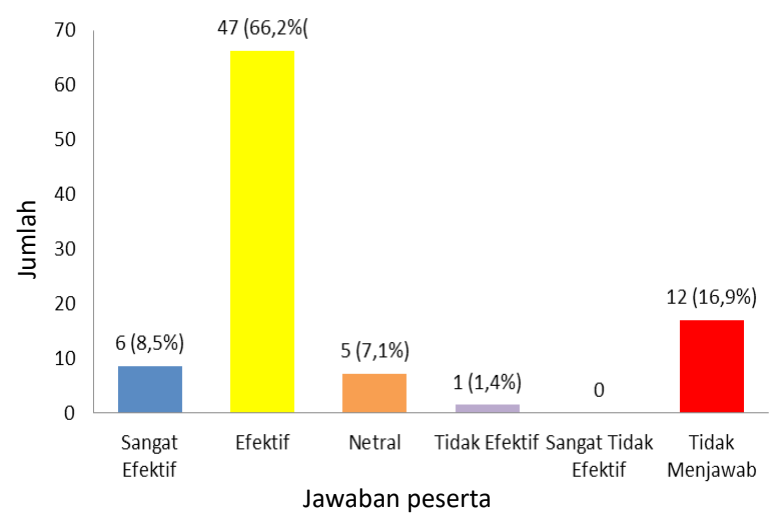

Gambar 3. Jawaban peserta terhadap pertanyaan bagaimana metode kegiatan yang dilakukan

Pemberian pelatihan petugas puskesmas dinilai baik untuk meningkatkan pengetahuan dan berdampak positif terhadap peningkatan keterampilan.

pemahaman. Metode yang digunakan dalam Metode ceramah merupakan sebuah bentuk pelatihan berupa penyuluhan atau ceramah, tanya interaksi edukatif melalui penerangan dan jawab atau diskusi, tutorial kasus dan praktikum penuturan secara lisan oleh pendidik terhadap 
sekelompok pendengar. Kelebihan dari metode ini adalah dalam waktu relatif singkat, materi dapat disampaikan ke pendengar sebanyak-banyaknya, dan pendidik dapat menguasai pendengar dengan mudah. Selain itu, metode ini dapat meningkatkan motivasi dan semangat belajar, serta ketentuannya fleksibel baik dari segi waktu maupun materi yang disampaikan. Adapun kekurangan metode ceramah adalah pendidik kesulitan mengetahui tingkat pemahaman pendengarnya dan pendengar mudah mengalami distraksi atau gangguan dalam menerima materi yang diberikan. ${ }^{11}$ Metode tanya jawab adalah teknik penyampaian materi yang dapat membantu menutupi kekurangan yang terdapat pada metode ceramah. Metode tanya jawab ialah cara penyampaian pelajaran dengan jalan pendidik mengajukan pertanyaan dan pendengar memberikan jawaban, atau sebaliknya. ${ }^{12}$ Metode ini merupakan metode pelengkap metode ceramah karena pada metode ini pendengar dapat mengklarifikasi atau meyakinkan ilmu yang didapatnya sudah sesuai dengan yang diharapkan pendidik atau belum. Selain itu, metode ini juga membuka kesempatan bagi pendengar untuk menggali ilmu lebih dalam dengan cara bertanya kepada pendidik.

Pemilihan metode pelatihan sudah tepat karena hasil evaluasi kegiatan menunjukkan bahwa sebagian besar peserta kegiatan menilai metode pelatihan efektif $(74,7 \%)$. Metode yang digunakan dalam kegiatan ini merupakan metode yang sudah biasa digunakan untuk penyampaian materi atau penyuluhan dengan modifikasi penambahan tutorial kasus dan praktikum agar peserta kegiatan tidak jenuh. Penelitian Kurniawan et al. menyebutkan bahwa pelatihan kader kesehatan dengan metode ceramah dan diskusi mampu meningkatkan pengetahuan kader kesehatan mengenai kesehatan ibu dan anak di wilayah Puskesmas Baturaden. ${ }^{13}$

\section{Kesimpulan}

Program pelatihan kepada petugas kesehatan di puskesmas (dokter, ahli gizi, dan ATLM) dapat meningkatkan pemahaman terkait anemia defisiensi besi. Hasil evaluasi program ini cukup baik dan diharapkan di masa mendatang dapat diadakan secara berkala, serta dapat ditularkan ke daerah lain sehingga tercipta peningkatan derajat kesehatan di masyarakat, khususnya terkait anemia defisiensi besi.

\section{Ucapan terima kasih}

Ucapan terima kasih kami berikan kepada Dinas Kesehatan Kabupaten Sleman dan seluruh petugas kesehatan di puskesmas di Kabupaten Sleman yang terlibat dalam kegiatan ini. Kegiatan pengabdian masyarakat dan penelitian ini didanai dengan hibah dari Program Pengabdian Kepada Masyarakat Berbasis Pemanfaatan Hasil Penelitian dan Penerapan Teknologi Tepat Guna, Universitas Gadjah Mada, 2018.

\section{Daftar pustaka}

1. Widiaskara I, Pramitha P, Suryawan IWB, Ugrasena I. Gambaran hematologi anemia defisiensi besi pada anak. Sari Pediatr. 2016;13(5):362.

2. Beard JL. Iron requirements in adolescent females. J Nutr. 2000;130(2):440S-2S.

3. Margina DS, Herawati $S$, Yasa IWPS. Diagnosis laboratorik anemia defisiensi besi. E-Jurnal Medika Udayana. 2014;3(1):58-69.

4. Amalia A, Tjiptaningrum A. Diagnosis dan tatalaksana anemia defisiensi besi. Medical Journal of Lampung University. 2016;5(5):1669.

5. Badan Penelitian dan Pengembangan Kementerian Kesehatan Republik Indonesia. Riset kesehatan dasar 2013. Jakarta: Departemen Kesehatan Republik Indonesia; 2013. 384 p.

6. Dinas Kesehatan Sleman. Rekapitulasi hasil penjaringan kesehatan peserta didik Kabupaten Sleman 2016. Sleman, D. I. Yogyakarta: Dinas Kesehatan Sleman; 2017.

7. Dinas Kesehatan Sleman. Laporan hasil identifikasi faktor-faktor yang berhubungan dengan kejadian anemia pada remaja putri 
di Godean. Sleman, D. I. Yogyakarta: Dinas Kesehatan Sleman; 2017.

8. Ringoringo HP, Windiastuti E. Profil parameter hematologik dan anemia defisiensi zat besi bayi berumur 0-6 bulan di RSUD Banjarbaru. Sari Pediatr. 2016;7(4):214.

9. Sari TT. Seng dan respons imun pada talasemia. Sari Pediatr. 2016;18(2):157.

10. Kementerian Kesehatan Republik Indonesia. Keputusan Menteri Kesehatan RI nomor 128 tahun 2004, Kebijakan dasar puskesmas.
Jakarta: Kementerian Kesehatan Republik Indonesia; 2004.

11. Zuhairini, Ghofir A. Metodologi pembelajaran. Malang: UM Press; 2004.

12. Hadi S. Metode pembelajaran. Yogyakarta: Andi Offset; 1993.

13. Kurniawan A, Gamelia E, Sistiarani C. Efektivitas pelatihan metode ceramah dan diskusi kader kesehatan untuk meningkatkan pengetahuan tentang kesehatan ibu dan anak di Puskesmas I Baturraden. Jurnal Kesmas Indonesia. 2017;9(1):23-33. 